DOI: $10.6060 / \mathrm{mhc} 160314 \mathrm{k}$

\title{
The First Macrocyclic Glycoterpenoid Having Glucosamine and Isosteviol Moieties
}

\author{
Bulat F. Garifullin, ${ }^{a}$ Irina Yu. Strobykina, ${ }^{a}$ Radmila R. Sharipova, ${ }^{a}$ \\ Marionella A. Kravchenko, ${ }^{\text {b }}$ and Vladimir E. Kataev ${ }^{\mathrm{a}}$ \\ ${ }^{a}$ Arbuzov Institute of Organic and Physical Chemistry, Kazan Scientific Center, Russian Academy of Sciences, 420088 Kazan, \\ Russia \\ ${ }^{\mathrm{b}}$ Ural Research Institute for Phthisiopulmonology, Ministry of Health Protection of the Russian Federation, 620039 \\ Ekaterinburg, Russia \\ ${ }^{\circledR}$ Corresponding author E-mail: kataev@iopc.ru
}

\begin{abstract}
The first macrocyclic glycoterpenoid possessing two glucosamine residues and two moieties of diterpenoid isosteviol has been synthesized. It inhibited the in vitro growth of the H37Rv strain of M. Tuberculosis at the MIC value of $12.5 \mu \mathrm{g} / \mathrm{mL}$.
\end{abstract}

Keywords: Terpenoids, isosteviol, glucosamine, glycosides, macrocycles, macrocyclic glycoterpenoids, antitubercular activity, Micobacterium Tuberculosis.

\section{Первый макроциклический гликотерпеноиА, содержащий остатки глюкозамина и изостевиола}

\author{
Б. Ф. Гарифуллин, ${ }^{a}$ И. Ю. Стробыкина, ${ }^{a}$ P. Р. Шарипова, ${ }^{a}$ М. А. Кравченко, \\ B. Е. Катаев ${ }^{\mathrm{a}}$
}

${ }^{\mathrm{a}}$ Институт органической и физической химии им. А.Е. Арбузова КазНЦ РАН, 420088 Казань, Россия

' Уральский НИИ фтизиопульмонологии Минздрава РФ, 620039 Екатеринбург, Россия

@E-mail:kataev@iopc.ru

\begin{abstract}
Синтезирован первый макроцчиклический гликотерпеноид с двумя остатками глюкозамина и двумя остатками дитерпеноида изостевиола. Он ингибирует in vitro рост итамма H37Rv Micobacterium Tuberculosis npu значении МИК 12.5 мкг/мл.
\end{abstract}

Ключевые слова: Терпеноиды, изостевиол, глюкозамин, гликозиды, макроциклы, макроциклические гликотерпеноиды, антитуберкулезная активность, Micobacterium Tuberculosis.

Recently we have reported the synthesis of macrocyclic glycoterpenoids having moieties of diterpenoid isosteviol and residues of glucuronic acid or trehalose. ${ }^{[1-4]}$ It was found that these macrocycles inhibited the in vitro growth of H37Rv strain of M. Tuberculosis at the minimal inhibition concentration (MIC) value of $12.5 \mathrm{mg} / \mathrm{mL}$ that is comparable to the activity of antitubercular drug pyrazinamide. ${ }^{[3,4]}$ Herein, the synthesis of the first macrocyclic glycoterpenoid having isosteviol and glucosamine residues is reported. We followed the previously proposed approach ${ }^{[1]}$ according to which the terminal reactive groups of binuclear isosteviol derivative are functionalized with carbohydrate residues, and these ones then are coupled by any linker.

The diol $\mathbf{1}^{[4]}$ was used as a starting compound in which two isosteviol molecules were bonded to each other with an octamethylene linker attached to their C(16) atoms, while carboxyl groups of these isosteviol moieties were functionalized by 6-hydroxyhexyl chains. The reaction of diol $\mathbf{1}$ with glucosamine bromo derivative $\mathbf{2}$ afforded diglycoside $\mathbf{3}$ in which amine groups were protected 
by trichloroethyl carbonate (Troc) groups. ${ }^{[5]}$ For the macrocyclization of diglycoside 3 its protecting groups were removed by the reaction with activated powdered zinc in glacial acetic acid, and diglycoside 4 were obtained in $87 \%$ yield. $†$ The MALDI spectrum of this compound demonstrated peaks at $m / z$ 1582.1, $\left[(M+\mathrm{H})^{+}\right]$, (calc. $m / z$ 1582.0, $\left[(M+\mathrm{H})^{+}\right]$, $\left.\mathrm{C}_{86} \mathrm{H}_{137} \mathrm{~N}_{2} \mathrm{O}_{24}\right), m / z$ 1604.1, $\left[(M+\mathrm{Na})^{+}\right]$, (calc. $m / z$ 1603.9, $\left.\left[(M+\mathrm{Na})^{+}\right], \quad \mathrm{C}_{86} \mathrm{H}_{136} \mathrm{~N}_{2} \mathrm{NaO}_{24}\right)$, and $m / z$ 1620.1, $\left[(M+\mathrm{K})^{+}\right]$, (calc. $m / z$ 1619.9, $\left.\left[(M+\mathrm{K})^{+}\right], \mathrm{C}_{86} \mathrm{H}_{136} \mathrm{KN}_{2} \mathrm{O}_{24}\right)$. In the ${ }^{1} \mathrm{H}$ NMR spectrum of diglycoside 4 the signals of the protons of Troc protecting group disappeared, and the signals of the protons at $\mathrm{C}^{2}$ atoms of glucosamine residues were shifted upfield in keeping with the literature data, ${ }^{[6,7]}$ and resonated as a doublet of doublets at $2.93 \mathrm{ppm}$ with vicinal coupling constants of 10.2 and $3.3 \mathrm{~Hz}$. The anomeric protons of diglycoside 4 resonated at $4.85 \mathrm{ppm}$ as a doublet with a vicinal coupling constant of $3.2 \mathrm{~Hz}$ indicating $\alpha$-orientation of the glycoside bonds. The reaction of diglycoside 4 with sebacoyl dichloride provided macrocyclic glycoterpenoid $5^{*}$ in $23 \%$ yield (after column chromatography). The MALDI spectrum of macrocycle 5 showed peaks at $m / z$ 1748.1, $\left[(M+\mathrm{H})^{+}\right]$, (calc. $m / z$ 1748.1, $\left.\left[(M+\mathrm{H})^{+}\right], \quad \mathrm{C}_{96} \mathrm{H}_{151} \mathrm{~N}_{2} \mathrm{O}_{26}\right), m / z$ 1770.1, $\left[(M+\mathrm{Na})^{+}\right]$, (calc. $m / z$ 1770.0, $\left.\left[(M+\mathrm{Na})^{+}\right], \mathrm{C}_{96} \mathrm{H}_{150} \mathrm{~N}_{2} \mathrm{NaO}_{26}\right)$, and $m / z$ 1786.1, $\left[(M+\mathrm{K})^{+}\right]$, (calc. $m / z$ 1786.0, $\left[(M+\mathrm{K})^{+}\right]$, $\mathrm{C}_{96} \mathrm{H}_{150} \mathrm{KN}_{2} \mathrm{O}_{26}$ ). In the ${ }^{1} \mathrm{H}$ NMR spectrum of macrocycle 5 the signals of protons of the diamide linker appeared, and the signals of the protons at $\mathrm{C}^{2}$ atoms of glucosamine residues were shifted downfield and resonated as a multiplet at 4.32-4.37 ppm. The anomeric protons of macrocyclic glycoterpenoid $\mathbf{5}$ appeared at $4.83 \mathrm{ppm}$ as a doublet with a vicinal coupling constant of $3.6 \mathrm{~Hz}$ that testified to the $\alpha$-orientation of the glycoside bonds.

The in vitro inhibitory activity of macrocyclic glycoterpenoid 5 toward the H37Rv strain of M. Tuberculosis

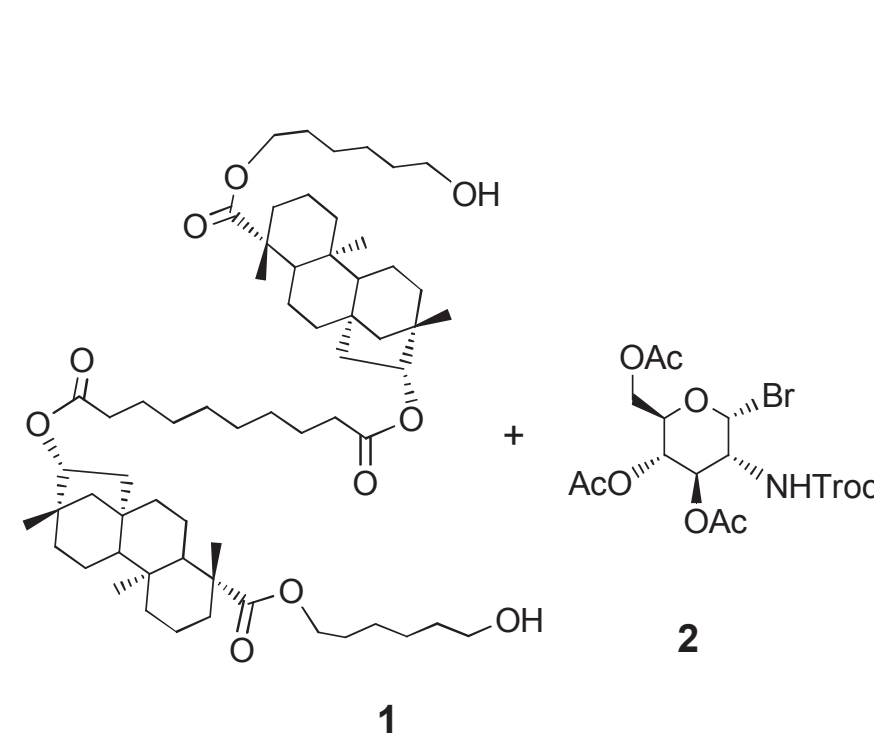

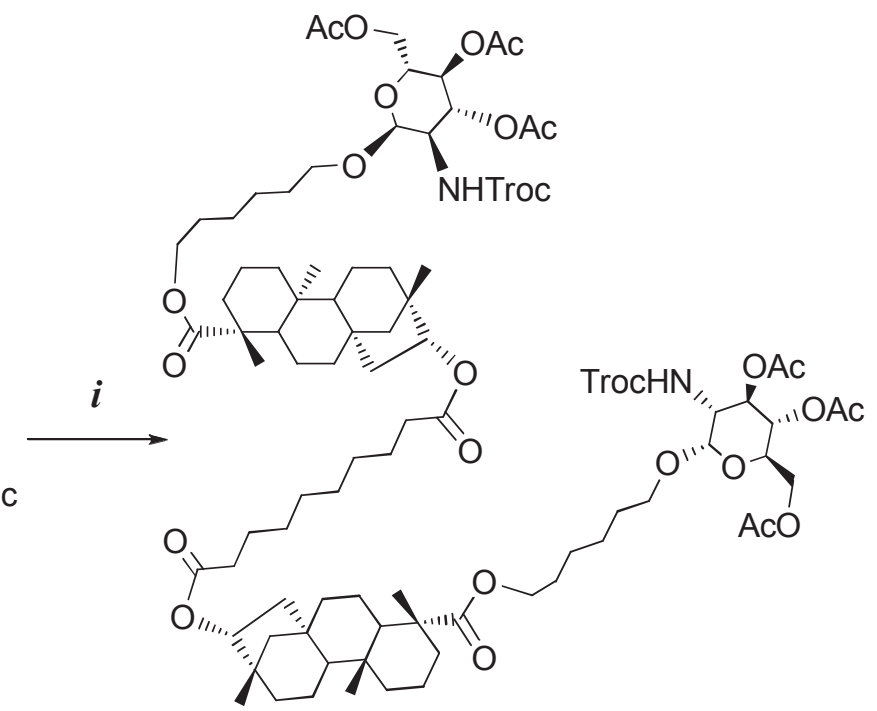

3

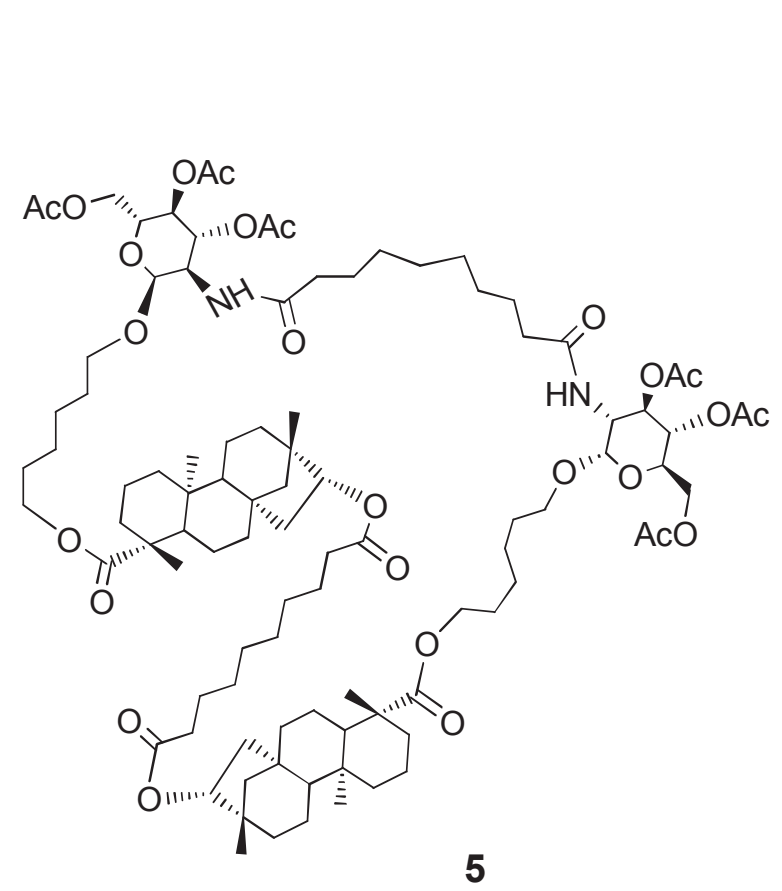

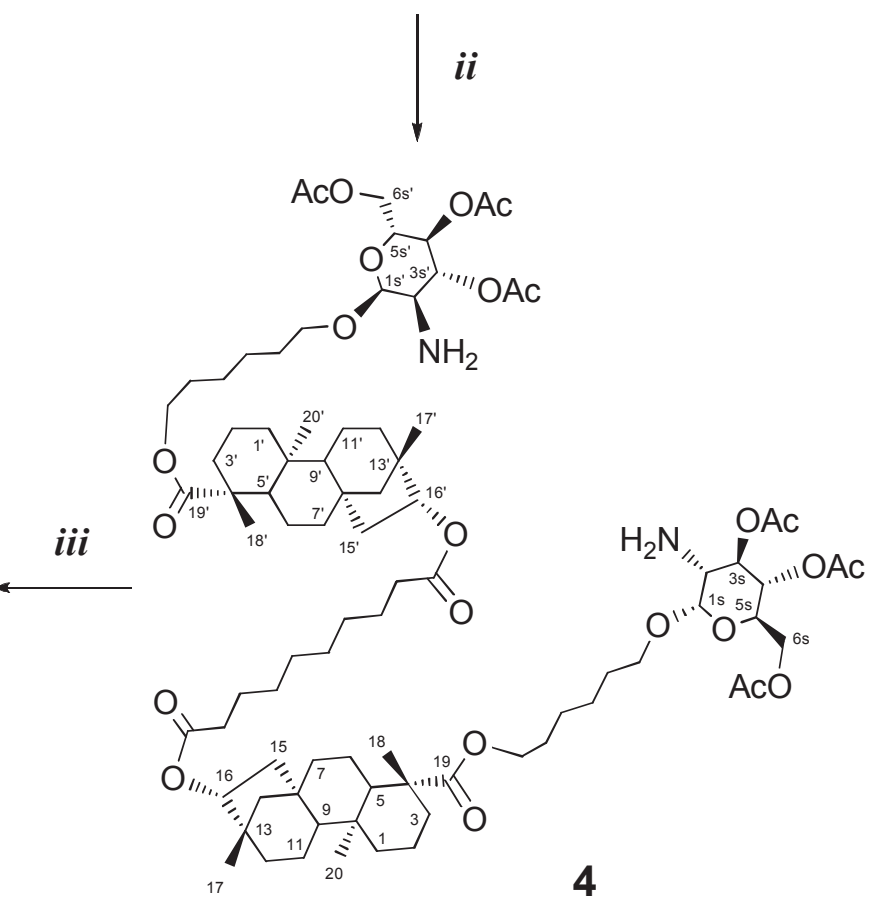

Scheme 1. Reagents and conditions: (i) $\mathrm{ZnCl}_{2}, \mathrm{CH}_{2} \mathrm{Cl}_{2}$, yield $20 \%$; (ii) $\mathrm{Zn}$, $\mathrm{AcOH}$, yield $87 \%$; (iii) $\mathrm{ClOC}\left(\mathrm{CH}_{2}\right)_{8} \mathrm{COCl}, \mathrm{CH}_{2} \mathrm{Cl}_{2}, \mathrm{Py}$, yield $23 \%$. 
was assayed. It was found that this compound inhibited the in vitro growth of this strain of patogen at MIC $12.5 \mu \mathrm{g} / \mathrm{mL}$, that is, at the level comparable to the known antitubercular drug pyrazineamide ${ }^{[8]}$ Comparing the obtained MIC value with those founded earlier for macrocyclic glycoterpenoids having residues of glucuronic acid ${ }^{[3]}$ and tregalose ${ }^{[4]}$ one can reveal that both the size of macrocycle and the nature of the carbohydrate residues do not influence on antitubercular activity of the macrocyclic glycoterpenoids under consideration.

In conclusion, the macrocyclic glycoterpenoid having two isosteviol moieties and two glucosamine residues bonded by polymethylene linkers with ester and amide groups has been synthesized for the first time. It inhibited the in vitro growth of the H37Rv strain of M. Tuberculosis at the MIC value of $12.5 \mu \mathrm{g} / \mathrm{mL}$.

Acknowledgments. The microbiological assay was performed under financial support of the Russian Science Foundation (grant № 14-50-00014).

\section{Notes and References}

Diglycoside (4). To a solution of diglycoside 3 (0.18 g, $0.09 \mathrm{mmol})$ in $\mathrm{AcOH}(4 \mathrm{~mL})$ powdered $\mathrm{Zn}(0.6 \mathrm{~g})$ was added under argon. The reaction mixture was stirred for $3 \mathrm{~h}$ at room temperature, then it was concentrated under reduced pressure. The residue was diluted with $\mathrm{CH}_{2} \mathrm{Cl}_{2}$, washed with $5 \% \mathrm{NaHCO}_{3}$ and water and brine, dried over $\mathrm{Na}_{2} \mathrm{SO}_{4}$ and concentrated under reduced pressure. Diglycoside 4 was obtained as white foam in $87 \%$ yield $(0.13 \mathrm{~g})$. Found, \%: C 65.05, H 8.49, N 1.68. $\mathrm{C}_{86} \mathrm{H}_{136} \mathrm{~N}_{2} \mathrm{O}_{24}$. Calculated, \%: C 65.29, H 8.66, N 1.77. Mass spectrum (MALDI TOF) $m / z(\%): 1582.1(100),\left[(M+\mathrm{H})^{+}\right], 1604.1(100),\left[(M+\mathrm{Na})^{+}\right]$, and $1620.1(100),\left[(M+\mathrm{K})^{+}\right] .{ }^{1} \mathrm{H} \mathrm{NMR}\left(400 \mathrm{MHz}, \mathrm{CDCI}_{3}, 30^{\circ} \mathrm{C}\right)$ $\delta$ ppm: $0.70\left(\mathrm{~s}, 6 \mathrm{H}, \mathrm{C}^{20} \mathrm{H}_{3}, \mathrm{C}^{20^{\prime}} \mathrm{H}_{3}\right), 0.90\left(\mathrm{~s}, 6 \mathrm{H}, \mathrm{C}^{17} \mathrm{H}_{3}, \mathrm{C}^{17^{3}} \mathrm{H}_{3}\right), 1.16$ $\left(\mathrm{s}, 6 \mathrm{H}, \mathrm{C}^{18} \mathrm{H}_{3}, \mathrm{C}^{18} \mathrm{H}_{3}\right), 0.81-1.89[\mathrm{~m}, 66 \mathrm{H}$, ent-beyeran skeleton, 2 linkers $\left(\mathrm{CH}_{2}\right)_{4}$ and linker $\left.\left(\mathrm{CH}_{2}\right)_{6}\right], 2.02\left(\mathrm{~s}, 6 \mathrm{H}, \mathrm{CH}_{3} \mathrm{CO}, \mathrm{C}^{\prime} \mathrm{H}_{3} \mathrm{CO}\right)$, 2.07 (s, 6H, $\left.\mathrm{CH}_{3} \mathrm{CO}, \mathrm{C}^{\prime} \mathrm{H}_{3} \mathrm{CO}\right), 2.08$ (s, 6H, $\left.\mathrm{CH}_{3} \mathrm{CO}, \mathrm{C}^{\prime} \mathrm{H}_{3} \mathrm{CO}\right), 2.15$ $\left(\mathrm{d}, 2 \mathrm{H}, J=13.5 \mathrm{~Hz}, \mathrm{C}^{3} \mathrm{H}_{\mathrm{eq}}, \mathrm{C}^{3} \mathrm{H}_{\mathrm{eq}}\right), 2.30\left(\mathrm{t}, 4 \mathrm{H}, J=7.4 \mathrm{~Hz}, \mathrm{C}^{16} \mathrm{OC}(\mathrm{O})\right.$ $\left.\mathrm{CH}_{2}, \mathrm{C}^{16} \mathrm{OC}(\mathrm{O}) \mathrm{CH}_{2}\right), 2.93\left(\mathrm{dd}, 2 \mathrm{H}, J=10.2,3.3 \mathrm{~Hz}, \mathrm{H}^{2 \mathrm{~s}}, \mathrm{H}^{2 \mathrm{~s}^{\prime}}\right)$,

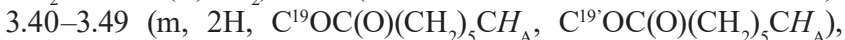
3.66-3.75 (m, 2H, $\left.\mathrm{C}^{19} \mathrm{OC}(\mathrm{O})\left(\mathrm{CH}_{2}\right)_{5} \mathrm{CH}_{\mathrm{B}}, \mathrm{C}^{19} \mathrm{OC}(\mathrm{O})\left(\mathrm{CH}_{2}\right)_{5} \mathrm{CH}_{\mathrm{B}}\right)$, 3.89-4.11 (m, 8H, $\left.\mathrm{H}^{6 \mathrm{~s}}, \mathrm{H}^{6 \mathrm{~s}^{\prime}}, \mathrm{C}^{19}(\mathrm{O}) \mathrm{OCH}_{2}, \mathrm{C}^{19^{\prime}} \mathrm{OC}(\mathrm{O}) \mathrm{CH}_{2}, \mathrm{H}^{5 \mathrm{~s}}, \mathrm{H}^{5 \mathrm{~s}^{\prime}}\right)$, $4.28\left(\mathrm{dd}, 2 \mathrm{H}, J=12.3,4.7 \mathrm{~Hz}, \mathrm{H}^{6 \mathrm{~s}}, \mathrm{H}^{6 \mathrm{~s}^{\prime}}\right), 4.72(\mathrm{dd}, 2 \mathrm{H}, J=10.5,4.2$ $\left.\mathrm{Hz}, \mathrm{C}^{16} \mathrm{H}, \mathrm{C}^{16} \mathrm{H}\right), 4.85$ (d, $\left.2 \mathrm{H}, J=3.2 \mathrm{~Hz}, \mathrm{H}^{1 \mathrm{~s}}, \mathrm{H}^{1 \mathrm{~s}^{\prime}}\right), 4.95(\mathrm{t}, 2 \mathrm{H}$, $\left.J=9.8 \mathrm{~Hz}, \mathrm{H}^{4 \mathrm{~s}}, \mathrm{H}^{4 \mathrm{~s}^{\prime}}\right), 5.12\left(\mathrm{t}, 2 \mathrm{H}, J=9.7 \mathrm{~Hz}, \mathrm{H}^{3 \mathrm{~s}}, \mathrm{H}^{3 \mathrm{~s}^{\prime}}\right)$.

"Macrocyclic glycoterpenoid (5). A solution of $0.012 \mathrm{~g}$ $(0.05 \mathrm{mmol})$ of sebacoyl dichloride in $\mathrm{CH}_{2} \mathrm{Cl}_{2}(3 \mathrm{~mL})$ was added to a solution of $0.08 \mathrm{~g}(0.05 \mathrm{mmol})$ diglycoside 4 and pyridine $0.008 \mathrm{~g}(0.1 \mathrm{mmol})$ in $\mathrm{CH}_{2} \mathrm{Cl}_{2}(5 \mathrm{~mL})$ under argon. The reaction mixture was stirred for $8 \mathrm{~h}$ at room temperature, then diluted with $\mathrm{CH}_{2} \mathrm{Cl}_{2}$, washed with $0.1 \mathrm{~N} \mathrm{HCl}$ and water, dried over $\mathrm{MgSO}_{4}$ and concentrated under reduced pressure. The residue was purified by silica gel column chromatography (eluent - hexane-ethyl acetate from 5:1 to 1:1 mixture). Compound $\mathbf{5}$ was obtained as a white foam in $23 \%$ yield $(0.02 \mathrm{~g}),[\alpha]_{D}{ }^{20}+13.8^{\circ}\left(c \quad 0.53 ; \mathrm{CH}_{2} \mathrm{Cl}_{2}\right)$. Found, \%: $\mathrm{C}$ 66.01, H 8.60, N 1.66. $\mathrm{C}_{96} \mathrm{H}_{150} \mathrm{~N}_{2} \mathrm{O}_{26}$. Calculated, \%: C 65.95, $\mathrm{H}$ 8.65, N 1.60. Mass spectrum (MALDI TOF) $\mathrm{m} / \mathrm{z}$ (\%): 1748.1 (100), $\left[(M+\mathrm{H})^{+}\right], 1770.1(93),\left[(M+\mathrm{Na})^{+}\right], 1786.1(83),\left[(M+\mathrm{K})^{+}\right] .{ }^{1} \mathrm{H}$ NMR $\left(500 \mathrm{MHz}, \mathrm{CDCl}_{3}, 30^{\circ} \mathrm{C}\right) \delta \mathrm{ppm}: 0.70\left(\mathrm{~s}, 6 \mathrm{H}, \mathrm{C}^{20} \mathrm{H}_{3}, \mathrm{C}^{20^{\circ}} \mathrm{H}_{3}\right)$, $0.91\left(\mathrm{~s}, 6 \mathrm{H}, \mathrm{C}^{17} \mathrm{H}_{3}, \mathrm{C}^{17} \mathrm{H}_{3}\right), 1.16\left(\mathrm{~s}, 6 \mathrm{H}, \mathrm{C}^{18} \mathrm{H}_{3}, \mathrm{C}^{18} \mathrm{H}_{3}\right), 0.80-1.89[\mathrm{~m}$, $78 \mathrm{H}$, ent-beyeran skeleton, 2 linkers $\left(\mathrm{CH}_{2}\right)_{4}$ and 2 linkers $\left.\left(\mathrm{CH}_{2}\right)_{6}\right]$, $2.00\left(\mathrm{~s}, 6 \mathrm{H}, \mathrm{CH}_{3} \mathrm{CO}, \mathrm{C}^{\prime} \mathrm{H}_{3} \mathrm{CO}\right), 2.03\left(\mathrm{~s}, 6 \mathrm{H}, \mathrm{CH}_{3} \mathrm{CO}, \mathrm{C}^{\prime} \mathrm{H}_{3} \mathrm{CO}\right.$ ), 2.09 (s, 6H, $\left.\mathrm{CH}_{3} \mathrm{CO}, \mathrm{C}^{\prime} \mathrm{H}_{3} \mathrm{CO}\right), 2.10-2.19\left(\mathrm{~m}, 6 \mathrm{H}, \mathrm{C}^{3} \mathrm{H}_{\mathrm{eq}}, \mathrm{C}^{3} \mathrm{H}_{\mathrm{eq}}, 2\right.$ $\left.\mathrm{NHC}(\mathrm{O}) \mathrm{CH}_{2}\right), 2.29-2.33\left(\mathrm{~m}, 4 \mathrm{H}, \mathrm{C}^{16} \mathrm{OC}(\mathrm{O}) \mathrm{CH}_{2}, \mathrm{C}^{16} \mathrm{OC}(\mathrm{O}) \mathrm{CH}_{2}\right)$,

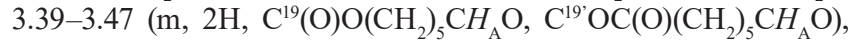
$3.65-3.71\left(\mathrm{~m}, 2 \mathrm{H}, \mathrm{C}^{19} \mathrm{OC}(\mathrm{O})\left(\mathrm{CH}_{2}\right)_{5} \mathrm{CH}_{\mathrm{B}} \mathrm{O}, \mathrm{C}^{19}(\mathrm{O}) \mathrm{O}\left(\mathrm{CH}_{2}\right)_{5} \mathrm{CH}_{\mathrm{B}} \mathrm{O}\right)$, 3.91-4.12 (m, 8H, $\left.\mathrm{C}^{19}(\mathrm{O}) \mathrm{OCH}_{2}, \mathrm{C}^{19^{\prime}}(\mathrm{O}) \mathrm{OCH}_{2}, \mathrm{H}^{6 \mathrm{~s}}, \mathrm{H}^{6 \mathrm{~s}^{\prime}}, \mathrm{H}^{5 \mathrm{~s}}, \mathrm{H}^{5 s^{\prime}}\right)$, $4.24\left(\mathrm{dd}, 2 \mathrm{H}, J=12.4,4.5 \mathrm{~Hz}, \mathrm{H}^{6 \mathrm{~s}}, \mathrm{H}^{6 \mathrm{~s}^{\prime}}\right), 4.32-4.38\left(\mathrm{~m}, 2 \mathrm{H}, \mathrm{H}^{2 \mathrm{~s}}\right.$, $\left.\mathrm{H}^{2 \mathrm{~s}^{\prime}}\right), 4.68\left(\mathrm{dd}, 2 \mathrm{H}, J=10.2,4.4 \mathrm{~Hz}, \mathrm{C}^{16} \mathrm{H}, \mathrm{C}^{16} \mathrm{H}\right), 4.83(\mathrm{~d}, 2 \mathrm{H}$, $\left.J=3.6 \mathrm{~Hz}, \mathrm{H}^{1 \mathrm{~s}}, \mathrm{H}^{\mathrm{ss}^{\prime}}\right), 5.11\left(\mathrm{t}, 2 \mathrm{H}, J=9.9 \mathrm{~Hz}, \mathrm{H}^{4 \mathrm{~s}}, \mathrm{H}^{4 \mathrm{~s}^{\prime}}\right), 5.21(\mathrm{t}, 2 \mathrm{H}$, $\left.J=10.0 \mathrm{~Hz}, \mathrm{H}^{3 \mathrm{~s}}, \mathrm{H}^{3 \mathrm{~s}^{\prime}}\right), 5.82(\mathrm{~d}, 2 \mathrm{H}, J=9.3 \mathrm{~Hz}, 2 \mathrm{NH})$.

NMR experiments were carried out with Avance-400 and Avance-500 (Bruker) spectrometers. MALDI mass spectra were obtained with a time-of-flight mass spectrometer Ultraflex III TOF/TOF (Bruker Daltonik GmbH, Bremen, Germany) equipped with a Nd:YAG laser and a collision cell. The spectra of positive ions were recorded in a reflectron mode and were processed using the software FlexAnalysis 3.0 (Bruker Daltonik GmbH, Bremen, Germany). ). Samples were prepared as $0.1 \%$ solutions of compounds in $\mathrm{CHCl}_{3}$. The matrix was $p$-nitroaniline (Acros). The completeness of the reactions and the purity of the compounds were monitored by TLC on Sorbfil plates (Sorbfil, Russia). Spots were detected by treatment with the $5 \%$ solution of sulfuric acid, followed by heating up to $120{ }^{\circ} \mathrm{C}$. Diglycoside 3 was synthesized according to the published procedure. ${ }^{[5]}$

${ }^{\S}$ Macrocyclic glycoterpenoid $\mathbf{5}$ was tested for antitubercular activity by the vertical diffusion method on a Novaya solid nutrient medium using H37Rv laboratory strain as a test culture. The nutrient medium was placed in $5 \mathrm{~mL}$ test tubes and inoculated with $0.1 \mathrm{~mL}$ of test culture diluted to a turbidity of 10 units (according to the standard developed by the Tarasevich State Scientific Research Institute for Standardization and Quality Control of Biologicals), and the test tubes were incubated for $24 \mathrm{~h}$ to grow tuberculosis bacteria. The test tubes were then set vertically, and $0.3 \mathrm{~mL}$ of a solution of 5 in aqueous alcohol with a concentration of 12.5, 6.2, $3.1,1.5,0.7,0.35$, or $0.1 \mu \mathrm{g} / \mathrm{mL}$ was added dropwise (test solutions were prepared by serial decimal dilutions of the initial solution of $100 \mu \mathrm{g}$ of macrocycle 5 in the mixture of $5 \mathrm{~mL}$ of $96 \%$ ethanol and $5 \mathrm{~mL}$ of sterile distilled water). The test tubes were incubated for 10 days at $37^{\circ} \mathrm{C}$ under sterile conditions, and the zone of bacterial growth inhibition was measured. An inhibition zone of longer than $10 \mathrm{~mm}$ indicated tuberculostatic activity. Antituberculosis drugs isoniazid which was used as a control inhibited M. tuberculosis growth at MIC $0.1 \mu \mathrm{g} / \mathrm{mL}$.

1. Andreeva O.V., Sharipova R.R., Garifullin B.F., Strobykina I.Yu., Kataev V.E. Chem. Nat. Compd. 2015, 51, 689-692.

2. Garifullin B.F., Sharipova R.R., Strobykina I.Yu., Andreeva O.V., Kataev V.E. Chem. Nat. Compd. 2015, 51, 886-889.

3. Andreeva O.V., Sharipova R.R., Strobykina I.Yu., Kravchenko M.A., Strobykina A.S., Voloshina A.D., Musin R.Z., Kataev V.E. Russ. J. Org. Chem. 2015, 51, 1324-1333.

4. Garifullin B.F., Sharipova R.R., Andreeva O.V., Strobykina I.Yu., Kravchenko M.A., Kataev V.E. Russ. J. Org. Chem., 2015, 51, 1488-1498.

5. Garifullin B.F., Strobykina I.Yu., Sharipova R.R., Bazanova O.B., Kataev V.E. Macroheterocycles 2016, 9, 54-58.

6. Miyajima K., Achiwa K. Chem. Pharm. Bull. 1997, 45, 312320.

7. De Nisco M., Pedatella S., Bektaş S., Nucci A., Caputo R. Carbohydrate Res. 2012, 356, 273-277.

8. Donald P.R. Tuberculosis 2010, 90, 279-292. 